\title{
Mapping Militant Manifestations in Balochistan Maryam Azam*
}

\begin{abstract}
Militant tendencies in Pakistan have been a leading security challenge because of its adverse effects on political, economic, social and ethnoreligious landscape of Pakistan. The case of Balochistan explicates the multivariate nature of militant manifestation in which nationalist and separatist aspirations tend to be a major tributary of militancy in Balochistan. The formation of militant groups on nationalistic and religious identities explains the two main sources of militant groups. Their linkages and networking further recognizes their operational capability and presence in the province. Moreover, geographical realities of the province along with its relationship with the federation and weak infrastructure, all contributes in shaping an environment which is conducive to militant tendencies in the shape of low intensity conflict. This article is based on a qualitative analysis which identifies genesis of militancy in Balochistan keeping in view the current changing geopolitical realities. After examining the facts, it is being concluded that traditionally call for separation is the driving force of militancy in Balochistan, however, ever since a decade, certain concentrated pockets of religiously grounded groups have been involved in target killing and suicide bombing.
\end{abstract}

Keywords: Insurgency, sectarianism, militant groups, separatism, grievances, security

* Dr. Maryam Azam, Assistant Professor in the department of International Relations, Lahore College for women university, Lahore, Pakistan

@ 2020 by the Islamabad Policy Research Institute.

IPRI Journal $\square \mathrm{XX}(2): 53-87$

https://doi.org/10.31945/iprij.200203.

IPRI JOURNAL $\bullet$ SUMMER 2020 


\section{Introduction}

alochistan has been subject to multifaceted traditional and $\mathrm{B}$ nontraditional security questions accompanied with the issues of political marginalization, resource distribution, socio-cultural and ethnic traits which have contributed in shaping up a fragile security environment of the province. Despite an energy and mineral based resourceful region, having the largest geographical area and strategically located at the crossroads of the contemporary geopolitical realities of the Asian continent, Balochistan province has been unable to gain its due place within the policy circles of Center since long. Even before partition, it was ruled by a separate political structure by British through the political agent ${ }^{1}$. After the independence of Pakistan, Balochistan got the provincial status after twenty-three years in 1970. In addition to that, it has been a bedrock of violence and armed struggle between the federal government and indigenous groups who were initially formed on the lines of nationalism and later split into nationalistic separatist groups and ethno national groups. ${ }^{2}$ Use of force by the state against such Baloch groups increased resentment and hostility against the federation and expanded the grounds for political and social instability in the region. Weak political and power structure usually provides a space to non-state actors to expand their domain in such vulnerable areas, as happened in Balochistan. Consequently, ethno-nationalist, separatist, sectarian, transnational and international militant outfits have gained strong foothold in Balochistan. It is evident that the security question of Balochistan is complicated and deep

1 Along with Balochistan, Tribal belt of Pakistan was also ruled through a separate code of conduct in order to retain their tribal and ethno cultural traits.

2 Initially, major demand of Baloch nationalist groups was of provincial autonomy. In addition to it, political parties were carriers of Baloch nationalism and demanded for provincial autonomy. Later, some groups (as discussed in the article) took a militant posture and also demanded separation from the federation. Therefore, nationalistic groups are now broadly divided into those who demand provincial autonomy within the federal structure and the ones who completely negate the idea of provincial autonomy, government writ and demand separation. See Also, Adeel Khan, "Renewed Ethno Nationalist Insurgency in Balochistan, Pakistan: The Militarized State and Continuing Economic Deprivation" Asian Survey 49, no. 6 (2009): 10711091, https://www.jstor. org/stable/10.1525/as.2009.49.6.1071. 
rooted. Therefore, this research paper intends to find out answers to the following research questions

- What are the main drivers of militancy and formation of militant groups in Balochistan?

- What are the local perceptions about this issue and how they have been affected by militancy?

\section{Nature and Genesis of Militancy in Balochistan}

Generically, militancy is a tendency in which an individual, or a group inflict violence, use force and does not comply with the constitutional sphere of the state. Challenging the writ of the government and proposing a change used on their own set agenda is a major feature of militant groups. Militancy in principle negates the norms of adaptability and coexistence, rather extremist and radical views are the main drivers of a militant. Therefore, militancy is defined as 'the fact of using, or willing to use force or strong pressure to achieve your aims, especially to achieve a social or political change.' ${ }^{3}$ The Oxford dictionary of Sociology defines militancy as 'willingness to engage in oppositional rhetoric and action."

Another explanation of militancy conceives it as 'a condition where mostly non-state actors use force against the state and masses at large. Moreover, psychologically they are enriched with radical, extremist and violent beliefs. ${ }^{5}$ In this regard, the notion of othering and exclusion is core to militant beliefs. ${ }^{6}$ Therefore, religious, ethnic, cultural, ideological and identity based factors become the main drivers of militancy. It is being observed that militancy has more context based description. Under this

3 Oxford Learner's Dictionary, s.v. "Militancy,” accessed on February 11, 2020, https://www.oxfordlearnersdictionaries.com/definition/english/militancy.

4 Gordon Marshall, Dictionary of Sociology (New York: Oxford University Press,1994),416.

5 Maryam Azam and Umbreen Javaid, "The Sources of Militancy in Pakistan," Journal of the Research Society of Pakistan 54, no.2 (July-December 2017): 189, http://pu.edu.pk/images/journal/history/PDF-FILES/13-Paper_54_2_17.pdf

6 Julia Eckert, "Theories of Militancy in Practice: Explanations of Muslim Terrorism in India," Social Science History 36, no.3 (Fall 2012): 321-328, https://www.jstor.org/stable/23258103. 
perspective, the complicated formations of nationalist, separatist, sectarian and anti-state groups define the nature of militancy in Pakistan. Moreover, political ostracism, poor economic and infrastructural conditions and closed social structures all contributed in providing a suitable area for militant tendencies to prevail in the province. The major centrifugal force of dissent within Balochistan seems to be the issue of resource distribution and economic deprivation which invariably affects all sectors of Baloch society. On the other hand, in terms of an identity orientation, there are two main fault lines in Balochistan, one is ethnic in nature and the other is sectarian. Population of the province is ethnically divided into Baloch, Brauhis and Pashtuns. Baloch population is predominately Sunni but a small fraction of Shia Hazara population resides in Quetta city which has been subject to target killing by the militants. ${ }^{\text {? }}$

Historically, Baloch as an ethnic identity, reside in parts of Pakistan, Iran and Afghanistan. It is evident that they have socio-cultural roots in the respective territories. Under the colonial rule, Britain used this area as a part of its imperial policy, as it comprised of four princely states i.e. Kalat, Lasbela, Kharan and Makran. Later, accession of Balochistan in Pakistan has not been smooth and peaceful rather an armed intrusion took place between the State of Kalat and armed forces of Pakistan. It is imperative to highlight that Muhammad Ali Jinnah was Khan of Kalat's legal representative to the British colonialists as it was Jinnah who rejected the proposal of Lord Mountbatten regarding the composition of the Electoral College of British Balochistan for referendum in which sardars nominated by the Khan of Kalat State were not part of Shahi Jirga. ${ }^{8}$ Despite the fact

7 They are mainly located in Marriabad and Hazara town.

8 Mohammad Ali Jinnah wanted the electoral college to be more democratic and people representative. Therefore, Jinnah proposed that Shahi Jirga and non-official members of Quetta municipality were not the true representatives of the province he rather proposed the inclusion of ration card holders, members of district jirga and all Maliks and Mutibars. See, Muhammad Iqbal Chawla, "Mountbatten and Balochistan: An Appraisal,"Proceedings of the Indian History Congress 75, Platinum Jubilee (2014) : 928-957; and Arup Kumar Sen, "Menace of Naxalism," Economic and Political Weekly 39, No. 49 (2004), https://www.jstor.org/stable/4415847. See also, Dushka H Saiyid, "The Accession of Kalat: Myth And Reality," Strategic Studies 26, No. 3 (Autumn 2006): 26-45. 
that Jinnah communicated to Khan of Kalat on the issue of merging with Pakistan, yet Pakistan had to use force in 1948, when Kalat state declared independence. ${ }^{9}$ It was on March 26, 1948, that Pakistan army was moved in Pasni, which is one of the coastal regions of Balochistan. ${ }^{10}$ Consequently, a Treaty of Accession was signed between Khan and the government of Pakistan. Therefore, it is evident that the seeds of dissent on identity, representation, ownership of resources and a friction towards federation remained there from the very start of independence. Furthermore, after the enactment of One Unit ${ }^{11}$ in Pakistan, another series of political and armed struggle started in Balochistan. Baloch representative had reservations over the political control of Punjab in particular, along with the representation of other provinces as well. The major concern sprouted from the fact that traditionally, Punjab, NWFP and Sindh had major chunk in bureaucracy, armed forces and politics respectively, which resulted in the lack of connectivity and mistrust between Balochistan and the Federal government of Pakistan. An armed rebellion of 1950s, which lasted for a couple of months, exposed the distrust which existed between certain factions within Balochistan and the Center. Marginalization of Baloch population due to One Unit was the main concern as most of the nationalists felt that it would compromise the autonomy of Baloch. That is the reason despite the fact that initially, Khan of Kalat agreed on One Unit system, he withdrew his support later and was accused of working for the succession of the Kalat State. ${ }^{12} \mathrm{He}$ was arrested

9 On $15^{\text {th }}$ August 1947, ruler of Kalat, Ahmad Yar Khan declared the independence as he claimed that the status of state of Kalat is same as of India and Nepal under the 1876 treaty which Kalat had with British India.

10 Yogeena Veena, "How Balochistan Became a Part of Pakistan - A Historical Perspective," Nation, December 5 , 2015, https://nation.com.pk/05-Dec-2015/howbalochistan-became-a-part-of-pakistan-a-historical-perspective.

11 The One Unit system refers to the policy constituted to merge the provinces residing in the then west Pakistan, i.e. Punjab, Balochistan, Sindh and North West Frontier Province (NWFP) into one larger administrative zone which was known as West Pakistan. It was announced on November 22, 1954, by the then Prime Minister Muhammad Ali Bogra and later came into force on October 5, 1955.

12 It was reported that in 1958 Khan of Kalat tried to get support from the Afghan government and also summoned Baloch sardars in Karachi for the restoration of Kalat state. See, Paul Titus and Nina Swidler, "Knights, Not Pawns: EthnoNationalism and Regional Dynamics in Post-Colonial Balochistan," International 
Maryam Azam

on October 6, 1958. Nauroz Khan, Sardar of Zarakzai tribe, along with his five hundred men revolted against the government. Later, he was also arrested and died in Kholu jail in $1964 .{ }^{13}$ Dissent on the ownership of resources emerged in 1950s when in 1958, dispute on the royalties on gas emerged. Sardar Bugti was the main recipient of royalties. In order to pressurize the government to increase the royalties, supply of gas from Sui was disrupted. Consequently, friction increased between the government and the Bugti tribe and armed forces used force against the tribal armed resistance. ${ }^{14}$ The seeds of an uneasy relationship and discontentment between the Baloch leaders and the government of Pakistan continued, which marked another serious rebellion in 1960s, particularly from 19621968. Meanwhile, the administrative structure of Balochistan remained complexed and feeble. In 1962 elections,${ }^{15}$ the big three of Balochistan, Attaullah Mengal, Ahmed Nawaz Bugti and Khair Bux Marri became members of the national assembly. They were critical of government's role in alienating Balochistan from the main stream socio political and economic priorities of the federation. Response of the government was reactionary and aggressive as they not only removed the title of sardars but later sardar of Marri and Mengal tribe were assassinated. ${ }^{16}$ The title of sardar has a symbolic value in the tribal structure of the society. Sardar acts as a system in Balochistan as it not only provides economic and social facilities to their clan member but also acts as a source of conflict management and resolution. ${ }^{17}$ For this purpose, relationship of a clan

Journal of Middle East Studies 32, No. 1 (February 2000): 47-69 (52), https://www.jstor.org/stable/259535.

13 "Killings of Zehris and History of Balochistan's Plight," News, April 13, 2013, https://www.thenews.com.pk/archive/print/424827-killings-of-zehris-and-history-ofbalochistan's-plight.

14 Rabia Aslam, "Greed, Creed, and Governance in Civil Conflicts: A Case Study of Balochistan," Contemporary South Asia 19, no. 2 (June 2011): 189-203 (194), https://doi.org/10.1080/09584935.2011.560654.

15 Indirect elections under the new Constitution were held on March 28, 1962.

16 Imtiaz Ali, “The Balochistan Problem," Pakistan Horizon 58, no. 2 (April 2005): 4162 (47), https://www.jstor.org/stable/41394092.

17 See, Moonis Ahmar, "Conflict Transformation as a Policy Change in South Asia: A Case Study of Balochistan," Journal of South Asian and Middle Eastern Studies 40, No. 3 (Spring 2017): 57-73 (62), https://www.jstor.org/stable/10.33428/ jsoutasiamiddeas.40.3.0057. 
member with its tribal leader is a dependent relationship and people are under complete control of the tribal leader. Therefore, the act of government halted the prestige and tribal norms. The use of force and reactive policy of the government in turn, also had a reactionary response from various factions in Balochistan. Gradually, the roots of dissent transformed into a militant behavior and resulted in the intensification of armed struggle.

The decade of 1970s further entrenched the roots of political turmoil and armed resistance. After the general elections of 1970, National Awami Party (NAP) $)^{18}$ came into power in which Baloch got representation and authority to exercise within the domain of provincial government. It was however, dismissed after ten months by Zulfiqar Ali Bhutto, mainly on account of the growing suspicion of federal government on the policies of provincial government, including their behavior towards non-Baloch settlers, steps to glorify the Baloch ethnic identity and the alleged involvement in London conspiracy. Certain factions of Baloch wanted to start an armed struggle against the federation with external support. In addition to that, a security situation was built with the support of the federal government in Lasbella and Pat Fedder to outlaw the provincial government. Moreover, the presence of Soviet weapons which were confiscated in Iraqi embassy in Islamabad, were linked with Baloch secessionist movement. Eventually, armed struggle started in Balochistan on nationalist and secessionist grounds in 1973 and it remained a high intensity conflict till 1977. This was the time when youth became radicalized and reactionary by taking up arms against the law enforcement

18 NAP formed in 1957 had membership from all major ethnic groups in Pakistan. It got majority seats in Balochistan in the general election. Federal government with the consultation of NAP appointed Sardar Ataullah Mengal as Chief Minister of Balochistan and Mir Ghaus Bakhsh Bizenjo as Governor of Balochistan, later after the dismissal Nawab Akber Bugti became the Governor of Balochistan. For more details also see, Rizwan Zeb, "Pakistan's Political Chess Board: Bhutto, Bugti and the National Awami Party Government in Balochistan (1972-1977)," Journal of South Asian and Middle Eastern Studies 42, No. 1 (Fall 2018): 67-87, https://www.jstor.org/ stable/10.33428/jsoutasiamiddeas.42.1.0067; and Nadeem F. Paracha, "The First Left," Dawn, November 9, 2014, https://www.dawn.com/news/1142900. 
Maryam Azam

agencies. It was a significant transformation of Baloch political and social order into conflict and chaos, thus strengthening the militant manifestations on ethnic lines. Later, during the regime of General Zia, ${ }^{19}$ tensions were diffused as several measures for reconciliation were taken by the government to maintain stability and order in the province.

Hence, the timeline is very significant to understand the infiltration of religious identity which later engulfed Balochistan into identity based fault line. After the Soviet intervention in Afghanistan in 1979, there was a major influx of Afghan refugees in Balochistan. Proportion of Pashtun population also increased during this time period. Moreover, it also gave rise to the growth of madaris developed on sectarian lines. The gradual Islamization of Balochistan resulted in the emergence of another strong competing identity in the shape of religiously driven groups and pockets. In this context, former chief minister of Balochistan, Dr. Abdul Malik stated that, "The last 30 years, the Afghan war and other ill-fated policies have affected Balochistan very negatively. As a result, religious extremism came to the province in the form of Shia-Sunni conflict. Extremism has been instilled in Balochistan since the time of Zia ul Haq in a very conscious and pre-planned way." 20

The fifth phase of insurgency in Balochistan during the regime of General Musharraf was the most complex and multifaceted in nature. The death of Nawab Akbar Bugti on August 26, 2006, accelerated the pace of armed confrontation and call for separation in Balochistan. In addition to that, presence of religiously driven militant groups further complicated the security environment of the province. The bleak security situation that started around 2002, from Kohlu and Dera Bugti, drastically escalated across Balochistan in 2006. One of the respondents recalling the days told that, 'I was studying in the university in Quetta, the environment was so tense that cars of armed forces evacuated us as we could not travel on bus.... Our university remained closed for around six months. A large

\footnotetext{
19 General Rahimuddin Khan was appointed as the Martial law administrator from 1977-1984.

20 Shah Meer Baloch, Herald, December 25, 2017, https://herald.dawn.com/news/ 1153954.
} 
number of youth belonging to educated middle class joined the insurgency against the government.' She further told that after doing her graduation she applied in a foreign university but couldn't get admission because she had a six months' gap in her semesters. Another respondent shared that this phase of insurgency has been different from the previous ones as this time a certain section of literate class joined the movement. He shared that according to him, since 2006, Balochistan has lost many young minds including poet, artist, lawyers and teachers. In this context, it is observed that though people in Balochistan expounds the militant mapping on ethnic separatist and religious grounds, they also equally link the case of militancy with the weak functioning of the government and the role of federal government in using force in the province.

Ethnic identity, reservation on the extraction of resources by outside powers with non-Baloch, mostly Punjabis, and demand of a separate Baloch state, are main drivers of Baloch nationalistic separatist groups. In this context, role of the federal government and use of armed forces in the province in different time period has triggered the scale of militancy in Balochistan. These groups are not religiously motivated but from the past several years, they have built connections with the sectarian and international militant groups at operational and tactical level. Therefore, they have entirely a separate set of demands as compared to the religion based groups. On the other hand, main driver of religion based groups is sectarian in nature. Their activities are an extension of an overall extremist wave in Pakistan that started in post 2001. After the military operations in the tribal belt, Balochistan gradually became another hide out for militants mainly because of its terrain and close proximity with FATA and Afghanistan. One common trait which connects these two distant nature of groups is their anti-state agenda. ${ }^{21}$ As far as their recruitment is concerned, mostly militant groups operate under shadows but with some local support. Therefore, as far as religion based groups are concerned, it seems that they tend to recruit from the locals for strong footing and hideouts in the province. In comparison to the Baloch separatist groups, their Baloch

21 For more details, see, Munir Ahmad, "The Battle for Pakistan Militancy and Conflict in Balochistan," (paper, New America Foundation, September 2011): 1-15. 
Maryam Azam

recruitment is less, as religion is not a driving force for Baloch dissidents. Similarly, both sets of militancy differ in terms of modus operandi. For instance, it is observed that suicide bombing is usually a tactic used by religion based militant groups and ethno nationalistic militant groups use hit and run tactics, IEDs, remote control bombing etc. It was in 2011, that BLA formed a group called Majeed Fidayeen Brigade which acts as a suicide bombing squad for the organization. It was first such group created by the ethno nationalistic groups in Balochistan. ${ }^{22}$

\section{Qualitative Analysis of local voices}

Following themes have been extracted from the focus group and in depth interviews from Baloch locals residing in Quetta, Turbat, Omara, Jhal Magsi, Jafarabad. These themes illuminate the reasons, nature and existence of militant manifestations in Balochistan.

\section{Main Themes}

\begin{tabular}{|l|l|}
\hline Theme I & $\begin{array}{l}\text { Militant Manifestations variate in terms of } \\
\text { geographic proximity. In post 2005 scenario, } \\
\text { Southern parts of Balochistan seems to have low } \\
\text { militant frequency as compared to northern parts of } \\
\text { Balochistan but from the past several years' } \\
\text { southern parts have witnessed frequent attacks } \\
\text { mainly against CPEC. Respondents belonging to } \\
\text { Turbat were mostly of the view that their region } \\
\text { has been considerably peaceful in the past, but } \\
\text { since the development of Gwadar and CPEC } \\
\text { project, militant activities have increased. On the } \\
\text { other hand, some respondents from Quetta recalled } \\
\text { the days after 2005 and told that they have seen } \\
\text { slogan of Azad Balochistan (Free/Independent }\end{array}$ \\
\hline
\end{tabular}

22 Farhan Zahid, "BLA's Suicide Squad: Majeed Fidayeen Brigade,” Terrorism Monitor XVII, No. 2 (January 2019): 1-10, https://jamestown.org/wpcontent/uploads/2019/ 01/TM-Jan.-25-2019-Issue-.pdf?x43515. 


\begin{tabular}{|l|l|}
\hline & $\begin{array}{l}\text { Balochistan) on the classroom walls of the } \\
\text { University of Balochistan, Quetta. In addition to it, } \\
\text { they were convinced with this fact that killing of } \\
\text { Hazara Shia is sectarian in nature and it has } \\
\text { increased due to the influx of religion based } \\
\text { militant groups for more than a decade. }\end{array}$ \\
\hline Theme II & $\begin{array}{l}\text { It was observed that the variable of education and } \\
\text { militancy has three distinct categories. }\end{array}$ \\
\cline { 2 - 3 } & $\begin{array}{l}\text { Category A- Areas having high literacy rate seems } \\
\text { to have low militant tendencies e.g. Makran } \\
\text { District (non-tribal structure). }\end{array}$ \\
\cline { 2 - 3 } & $\begin{array}{l}\text { Category B- Areas having high literacy rate seems } \\
\text { to have high militant tendencies e.g. Quetta. }\end{array}$ \\
\cline { 2 - 2 } & $\begin{array}{l}\text { Category C- Areas having low literacy seems to } \\
\text { have high militant tendencies e.g. District Kalat. }\end{array}$ \\
\hline
\end{tabular}

23 Militancy in most cases has a context based explanation. In this regard, militancy in Pakistan is a product of multifaceted factors including socio political, ethnic, religious and external factors. Education sector in this regard has been seen as a major contributing factor in accelerating extremist tendencies among the youth. Number of studies have built a relationship between education and militancy in Pakistan as it becomes a major tributary through which radicalization and extremism can be indoctrinated. For more details, see Rebecca Winthrop and Corinne Graff, "Beyond Madrasas: Assessing the Links between Education and Militancy in Pakistan," Center for Universal Education at Brookings 2, (June 2010): 1-64. In addition to it, after 2001, initially most of the literature revolve around the nature, role and content of madarris and their connections with the militant groups, but later law enforcement agencies were concerned about the inclusion of militants belonging to public and private sector universities. For details see, Christine C. Fair, The Madrassah Challenge: Militancy and Religious Education in Pakistan (Lahore: Vanguard Books, 2009); Madiha Afzal, "University Education and Radicalization in Pakistan," April 16, 2018, https://www. livemint.com/Opinion/sO39a731fTHzAWEjJuCvuI/University-education-andradicalization-in-Pakistan.html. Another link of education and militancy in Pakistan is the presence of student unions associated with certain religious and ethnic groups on the university campuses. In Balochistan, Baluchistan Student Organization-Azad has been very active in and out of campus. See also, Annexure I. 
Maryam Azam

\begin{tabular}{|c|l|}
\hline Theme III & $\begin{array}{l}\text { The inclusion of middle class in the insurgent } \\
\text { campaign has sprouted a new generation of groups } \\
\text { which has made the overall environment more } \\
\text { complex and multifaceted }\end{array}$ \\
\hline Theme IV & $\begin{array}{l}\text { People tend to have strong apprehensions on the } \\
\text { role of local sardars in spending the budget on the } \\
\text { social needs of the population. Invariably, all the } \\
\text { respondents had strong reservations on the lack of } \\
\text { infrastructural development and basic facilities of } \\
\text { life. Role of sardars and politician is also crucial } \\
\text { in resolving the economic and social problems of } \\
\text { the province. }\end{array}$ \\
\hline Theme V & $\begin{array}{l}\text { Infrastructural development, education, } \\
\text { employment and political mainstreaming are three } \\
\text { main proposals given by the respondents. }\end{array}$ \\
\hline Theme VI & $\begin{array}{l}\text { Since a decade, sectarian militancy is observed to } \\
\text { be a major challenge in the urban areas, mostly } \\
\text { northern areas of the province. However, ethno } \\
\text { separatist and sectarian groups have not been allied } \\
\text { yet. Otherwise it could have been more devastating } \\
\text { and damaging for the province. }\end{array}$ \\
\hline Theme VII & $\begin{array}{l}\text { The role of armed forces since 1970s has been } \\
\text { critical in understanding and countering the issues } \\
\text { in Balochistan. }\end{array}$ \\
\hline $\begin{array}{l}\text { State does not understand the meaning of Baloch } \\
\text { nationalism instead, it is understood more in the } \\
\text { context of separatism within the federation. }\end{array}$ \\
\hline VIII
\end{tabular}

The above backdrop of Balochistan issue and the opinion of local voices expounds the existence of two main militant manifestations in the province. 
One is ethno-separatist, which is more indigenous, traditional, socially constructed and strong and the other one is religious, which is more contemporary, sectarian having external offshoots as well. In this context, the case of Balochistan can be well understood through its geography and spread of population. Quetta, Mastung, Kachhi district(Bolan), Jal Magsi, Sibi and Pashtun populated areas are dominated with religious tendencies whereas Dera Bugti, Kohlu, Nasirabad and Jaffarabad, ${ }^{24}$ are highly tribal structured areas where ethnic separatist element is dominant. Along with this, Makran belt is non-tribal in nature with certain clusters of nationalist as well as sectarian pockets. From the past few years, Makran belt has faced some terrorist attacks which are linked with the energy corridor politics of CPEC. Therefore, the role of external forces is also evident in these areas.

Another significant factor is the institutionalization of militant orientations in the form of ethno separatist, sectarian and transnational groups. Group formation in militant movement explicates the deep rooted support and supply system of the organization. Moreover, mostly groups provide a common ideological standing and motivation for the recruits. In this context, theoretical illustrations of militant and terrorist organizations provides an insight into the working, nature and agenda setting of such groups. Martha Crenshaw while explaining the institutional and organizational dimension of extremist and terrorist groups identifies that external changes in the political and social order of a society in general, and actions of the government have a profound influence on the working of the organizations. In addition to that, internal functioning of the organizations is a product of many factors including leadership,

24 Extracted from the talks with the locals. Also see, "IS In Jhal Magsi," Nation, October 7, 2017,https://nation.com.pk/07-Oct-2017/is-in-jhal-magsi;Zia ur Rehman, "Sindh's Most Wanted Terrorist Killed," accessed December 19, 2019, https://www.geo.tv/latest/ 230128-sindhs-most-wanted-terrorist-killed; and Saba Imtiaz, "Massacre in Mastung," Foreign Policy: The South Asian Channel, September 21, 2011, https://foreignpolicy.com/2011/09/21/massacre-in-mastung/; and Syed Ali Shah, "Five Suspected Militants Killed in Balochistan's Sibi," Dawn, November 29, 2011, https://www.dawn.com/news /1299411/five-suspectedmilitants-killed-in-balochistans-sibi; and Imtiaz Ali, "Balochistan's Maze of Violence," Center for Research and Security Studies, (2011): 12-44, https://crss.pk/wp-content/uploads/2010/07/Balochistans-Maze-of-Violence.pdf. 
competitive environment, resource incentive and ideological traits to attract new recruits for the sustainability of the group. ${ }^{25}$ In case of Balochistan, the external stimuli for the militant groups is mainly driven by the use of force by the federal government, resource distribution and ethnic marginalization on the basis of which groups have taken a militant and separatist posture. Militants derive their strength within the local strata mainly ethnic and in certain cases from religious doctrine. In addition to that, identity based factors also facilitate the groups to maintain the valor and motivation within the group. These ideological traits act as a main incentive for the recruits of militant groups to take part in the organizational activities. Thus, ethnic and religious reasons provide a cause to a militant group on the basis of which their organizations sustain. Likewise, Rethemeyer explains the link between the ideology of the organization and its lethality. Ideology in this regard provides a framework under which a group operates and set its targets. ${ }^{26}$ The ideological beliefs and values provide a benchmark to distinguish between themselves and others. ${ }^{27}$ Othering separates their own group with all others on the basis of which militant groups legitimize their lethal actions against others.

This study further entails that groups based on religious, ethnicity and religious ethno nationalist beliefs tend to be more lethal and hazardous in their activities. The religious and ethnically grounded audience have been an important factor in explaining the action of groups. Besides this, militant groups having connections and networking with peers also have the tendency to inflict more damage and harm. In case of Balochistan, this illustration is very useful to understand the nature and working of militant groups in the province.

25 Martha Crenshaw, "Theories of Terrorism: Instrumental and Organizational Approaches," Journal of Strategic Studies 10, no. 4 (1987): 13-31, https://doi.org/ 10.1080/01402398708437313.

26 Victor Asal and R. Karl Rethemeyer, "The Nature of the Beast: Organizational Structures and the Lethality of Terrorist Attacks," Journal of Politics 70, no.2 (April 2008): 437-449, https://www.jstor.org/stable/10.1017/s0022381608080419.

27 The writer termed it as 'boundary activation' in which militant and terrorist groups project their own self-righteousness on the basis of some strong ideology excluding all other beliefs and point of views. 
In addition, ethno separatist groups mainly get their recruits and support system by exploiting the peer factor and ethnic identity. On the other hand, religious groups have been able to articulate a supernatural source of motivation with the tool of inducing their own self-righteousness in the society and excluding all other religious discourse by othering them. Attacks on Shia population in general and Shia-Hazara population (Ethnoreligious identity) in particular, illustrates this character of militant groups.

In this regard, following groups expound the militant construction in Balochistan which can be broadly divided into ethno separatist and religious in nature.

Table I

Militant groups in Balochistan

\begin{tabular}{|l|l|l|l|}
\hline $\begin{array}{l}\text { Greater } \\
\text { Balochistan } \\
\text { and Separatist } \\
\text { groups }\end{array}$ & $\begin{array}{l}\text { Militant and } \\
\text { sectarian groups }\end{array}$ & $\begin{array}{l}\text { Transnational } \\
\text { groups that } \\
\text { function between } \\
\text { Afghanistan and } \\
\text { Pakistan }\end{array}$ & $\begin{array}{l}\text { Militant groups } \\
\text { that function } \\
\text { between Iran } \\
\text { and Pakistan }\end{array}$ \\
\hline $\begin{array}{l}\text { Baloch Republican } \\
\text { Army (BRA) }\end{array}$ & $\begin{array}{l}\text { Tehrik Taliban } \\
\text { Pakistan (TTP) }\end{array}$ & Al Qaeda & $\begin{array}{l}\text { Baloch Raaji } \\
\text { Aajoi Sangar } \\
\text { (BRAS) }\end{array}$ \\
\hline $\begin{array}{l}\text { Baloch Liberation } \\
\text { Army(BLA) }\end{array}$ & $\begin{array}{l}\text { Ghazi Force } \\
\text { (splinter group } \\
\text { of TTP) }\end{array}$ & $\begin{array}{l}\text { Islamic State } \\
\text { (IS) }\end{array}$ & $\begin{array}{l}\text { Jaish al Adl } \\
\text { (Army of } \\
\text { Justice) }\end{array}$ \\
\hline $\begin{array}{l}\text { Balochistan } \\
\text { Student } \\
\text { Organization } \\
\text { (BSO) - Azad }\end{array}$ & $\begin{array}{l}\text { Laskar e Jangvi } \\
\text { Al Alami LeJ- } \\
\text { AL }\end{array}$ & $\begin{array}{l}\text { Hizbul Ahrar } \\
\text { (HuA) }\end{array}$ & - \\
\hline $\begin{array}{l}\text { Lashkar e } \\
\text { Balochistan }\end{array}$ & $\begin{array}{l}\text { Difa-e- } \\
\text { Balochistan }\end{array}$ & & \\
\hline
\end{tabular}

IPRI JOURNAL — SUMMER 2020 
Maryam Azam

\section{Ethnic identity based indigenous militant clusters}

Insurgencies in Balochistan have been mainly dominated by various factions located in specific areas in the north and south of Balochistan. Most of the groups are localized and are formed on ethnic identity and call for separatism. Ethno separatists' forces are the most dominated militant sources in Balochistan. In addition to that, there is a common trait among the group leaders to take safe hide in Afghanistan which has not only outsourced the Baloch issue but has also paved the way to create linkages with the exterior sources. These groups tend to have a militant posture as they use force against government installations and even civilians. In the recent past, linkage between the groups have also been observed which increase their overall operational and tactical capability.

From the past few years, Baloch nationalist separatist groups have increased their activities in the Makran belt mainly because of Gwadar port project and CPEC. Therefore, they have been involved in attacks on Pakistan armed forces, Chinese national and non-Baloch identities. Following groups can be mapped out in different areas in Balochistan:

\section{Baloch Liberation Front (BLF)}

BLF was formed in 1964 with ethno political posture, which demands separation from Pakistan. BLF has been involved in cross border activities as they joined Baloch revolt groups in Iran who were fighting against the government of Iran in 1970s. The geographical proximity facilitated them in operating in the Iranian province of Balochistan. The group took up arms against the state and demanded separation from Pakistan. As a part of groups fighting against Shah of Iran, they were also supported by Iraq. Eventually, their role was minimized when Iranian Baloch groups signed a peace treaty with their government in 1973. Consequently, from 19731977, BLF was then involved in articulating insurgency against the state of Pakistan in Balochistan province. ${ }^{28}$ It aims to end the role of federation in the natural resources of Balochistan. BLF is extensively involved in

\footnotetext{
${ }^{28}$ Stanford University, "Mapping Militant Organizations, Balochistan Liberation Front," accessed November 19, 2019, https://web.stanford.edu/group/mappingmilitants/cgibin/groups/view/457.
} 
indiscriminate attacks on Pakistani armed forces. Currently, it is headed by Dr Allah Nazar. ${ }^{29}$ In an interview given by Dr. Allah Nazar to BBC in 2015, he openly stated that whosoever would support the state of Pakistan against our agenda would not be forgiven by BLF. ${ }^{30}$ It was declared as a terrorist group by US in July 2019.

\section{Baloch Republican Army (BRA)}

BRA is ethno nationalistic separatist group founded in 2006, by Brahamdagh Bugti. ${ }^{31}$ Most of the recruits belong to Bugti tribe. It is said to be the militant wing of Balochistan Republican Party (BRP) using social media to connect and expand their agenda through Twitter and Facebook accounts. BRA has targeted law enforcement agencies, infrastructure (electricity and railways) and personnel of international oil companies. ${ }^{32}$ BRA reportedly have some links with the militant groups like LeJ and Jandullah. Though, they don't share an ideological affiliation but both have common anti state agenda. ${ }^{33}$ Moreover, their links and tilt towards India is also critical. One of their leaders, Sher Mohammad Bugti stated that, "we want India to help us militarily, like its intervention in the support of Bengali [nationalists] in 1971." ${ }^{34}$

\footnotetext{
29 He belongs to Mashkay in district Awaran.

30 "Dr Allah Nazar Baloch Details Baloch Resistance to Pakistan's Violent Occupation of Balochistan," posted by Shawn Forbes, August 2015, video, 11:04,https://www.youtube.com/watch?v=ZLXaskGwEpM.

$31 \mathrm{He}$ is the grandson of leader of Bugti tribe, Nawab Akbar Bugti (former Minister of State for Interior, and former Governor, of Balochistan) who was killed in 2005 in a mountain cave allegedly by law enforcement agencies.

32 Imtiaz Ali, "Balochistan's Maze of Violence," (Islamabad, Center for Research and Security Studies), 47, https://crss.pk/wp-content/uploads/2010/07/BalochistansMaze-of-Violence.pdf.

33 Jawad R. Awan, "Joint terror ventures in Balochistan,"The Nation, October 18, 2016; and Jawad R. Awan "Joint Terror Ventures in Balochistan," Nation, October 18, 2016 , https://nation.com.pk/18-Oct-2016/joint-terror-ventures-in-balochistan.

34 Abdul Hai Kakar and Abubakar Siddique, "Baluch Separatists Call for India to Intervene Like In Bangladesh," Gandhara, September 16, 2016, https://gandhara.rferl.org/a/pakistan-balochistan-india-bangladesh/27993409.html.
} 


\section{Baloch Liberation Army (BLA)}

BLA is a banned operational militant group in the southwest of Balochistan since 2000. Most of the recruits belong to Bugti and Marri tribe. BLA is one of those groups which has foot prints in 1973-1977 insurgency led by Khair Bakhsh Marri. Later his sons, Balach Marri and Habiyar Marri ${ }^{35}$ organized BLA. The group also showed its resentment over Chinese investment and their growing influence in Gwadar ${ }^{36}$ Recently, it has been reportedly involved in the terrorist activities in Gwadar and against law enforcement agencies. Pakistan's claim that BLA has sanctuaries in Afghanistan and Iran, reflects the complex nature of militant nexus, as the outsourcing of the group connects it with the transnational militant groups across the borders. ${ }^{37}$ It was declared as a terrorist group by US in July 2019. BLA has been using social media to expand support and information. It is being observed that many Twitter accounts regularly report the activities of the group in which they usually credit the attacks on law enforcement agency. In addition to that, BLA has been subject to intra group rivalry

35 Khair Bakhsh Marri became the member of national assembly as well but he was the staunch supporter of Baloch separate homeland. His son Balach Marri led BLA, he was killed in Afghanistan on 21 November 2007, which explicates their links and strong base for hideout in Afghanistan. See Hasan Mansoor, "Khair Bakhsh Marri: A Fighter all the Way," Dawn, June 14, 2014, https://www.dawn.com/news/1111939. Harbiyar Marri is a separatist activist and son of Baloch leader Khair Bakhsh Marri. $\mathrm{He}$ is a separatist activist and son of Baloch leader Khair Bakhsh Marri. He is being living in London for the past many years. Marri supports free Balochistan movement and was also invited in Delhi for a conference on Balochistan which made him more critical in front of security agencies of Pakistan. Reportedly he was also behind the attack on Chinese consulate in Karachi in 2018. See also, "Delhi conference where Baloch leader Hyrbyair Marri was to speak gets postponed" accessed on November 19,2019 https://www.business-standard.com/article/news-ani/delhi-conference-where-balochleader-hyrbyair-marri-was-to-speak-gets-postponed-118120600915_1.html

36 Frederic Grare, "Balochistan: The State Versus the Nation," Carnegie Endowment for International Peace (April 2013): 8-10, https://carnegieendowment.org/files/ balochistan.pdf; and Center for International Security and Cooperation (CISAC), "Balochistan Liberation Army," accessed November 15, 2019,

https://cisac.fsi.stanford.edu/mappingmilitants/profiles/balochistan-liberation-army.

37 Umair Jamal, "The Baloch Liberation Army's New US Terrorist Designation: Why Now?" Diplomat, July 9, 2019, https://thediplomat.com/2019/07/the-balochliberation-armys-new-us-terrorist-designation-why-now/. 
which resulted in the formation of United Baloch Army (UBA), a separatist militant group led by Mehran Marri after his rift with Harbiyar Marri. ${ }^{38}$ Another splinter group of BLA, Lashkar e Balochistan came on the forefront in 2012, when they claimed the bomb attacks in Quetta, Karachi and Lahore. This was a new tendency in Baloch separatist groups that they operated from outside the frontiers of Balochistan. They have been involved in targeting government installations, gas pipe lines and police force from 2012 -2017. Later, the group became inactive as the militants associated with them were arrested by the law enforcement agencies in 2017 under intelligence based operations. ${ }^{39}$

Another new formation within the militant groups is the informal linkages between nationalistic separatist groups and religious based groups. It is being reported that BLA tend to have informal links with IS affiliates in Balochistan (mostly the local cadre) and LeJ (which is involved in sectarian killings). Even the links between LeJ and BLA were expressed by former interior minister, Rehman Malik. ${ }^{40}$ This kind of nexus is a serious concern for the law enforcement agencies as it would not only expand the sphere of activities of the groups within and outside Balochistan but would also strengthen them in operational activities. ${ }^{41}$ BLA has been very active

38 He is the youngest son of Khair Bakhsh Marri and brother of Harbiyar Marri. Being a separatist Mehran Marri demands the separation of Balochistan from Pakistan. His anti-Pakistan posture is quite visible from his twitter account. For instance, he has used the phrases like, "Pakistan occupied Balochistan", "OCCUPIED Balochistan" and "Pakistan's genocide in occupied Balochistan." For further details, see, Dopel, "Data Base of People with Extremist Linkages," accessed November 30, 2019, https://dopel.org/UBA.htm; Fahad Nabeel, "Factionalism in the Baloch Insurgency: An Overview," Stratagem, accessed November 30, 2019,https://stratagem.pk/armeddangerous/factionalism-balochistan-insurgency-overview/.

39 Imran Awan, "LeB Terrorist Involved in Blasts Arrested," Daily Times, September 16,2017 , https://dailytimes.com.pk/116607/leb-terrorist-involved-in-blasts-arrested/.

40 In 2012, the then interior minister claimed that BLA and LeJ has links from the past five years. See, "BLA, LeJ responsible for Balochistan unrest: Malik" August 02, 2020, https://www.dawn.com/news/739179/baloch-liberation-army-responsible-forbalochistan-unrest-says-malik.

41 Barbara Kelemen, "China's Twofold CPEC Strategy In Pakistan: Present Security Challenges and Future Prospects in Pakistan," (paper, Institute of Asian Studies, 2018), 7-8, https://ceias.eu/wp-content/uploads/2018/09/ChinaPakistan_Kelemen_fin.pdf. 
Maryam Azam

from the past several years across Balochistan. In 2018, BLA, the first Baloch nationalist group which conducted suicide bombing, targeted a bus carrying Chinese engineers from Dalbandin to Quetta. ${ }^{42}$ This attack reflected their resentment towards CPEC project and their anti-state posture.

\section{Baloch Raaji Aajoi Sangar (BRAS) $)^{43}$}

BRAS is a loose armed alliance of Baloch separatist ethnic groups including BLA, BLF and Baloch Republican Guards (BRG), formed in 2018. It is significant to note that it is the first nexus between Baloch separatist groups as previously these groups had their own independent sphere of activities. Dr. Allah Nazar Baloch is the main architect of this alliance. In one of his interviews published on a website, Nazar Baloch stated that 'Baloch Liberation Front, Baloch Liberation Army, Baloch Republican Army and the United Baloch Army all are fighting for Baloch independence and there is no difference between us. ${ }^{24}$ The main objectives of the alliance revolves around the following points

- Establishment of a separate Baloch state.

- Exclusion of outside powers from Balochistan (for instance, China).

- Expulsion of non-Baloch in the extraction of resources and mega projects (mainly Punjabi). ${ }^{45}$

42 Saleem Shahid, "Three Chinese Engineers among Five Injured in Dalbandin Suicide Attack," Dawn, August 12, 2018, https://www.dawn.com/news/1426550. See also," Attack on Chinese engineers in Balochistan," Pak Institute for Peace Studies, August 27, 2018, https://www.pakpips.com/article/3510.

43 Baluch National Freedom Movement.

44 “ ‘6000 Baloch Militants Resisting Pak Army’: Allah Nazar Baloch,” Punjnud, accessed September 15, 2020,

https://www.punjnud.com/ViewPage.aspx?BookID=13346\&BookPageID=309164\& BookPageTitle $=\%$ E2\%80\%986000\%20Baloch $\% 20$ Militants $\% 20$ Resisting $\% 20 \mathrm{Pak} \%$ 20Army\%E2\%80\%99:\%20Allah\%20Nazar\%20Baloch.

45 Farhan Zahid, "Baluch Raji Ajohi Sangar: Emergence of a New Baluch Separatist Alliance" Terrorism Monitor XVII, No.18 (September 2019): 6-7, https://jamestown.org/wp-content/uploads/2019/09/TM-Sep.-20-2019-Issue1.pdf?x39443. 
In 2019, they claimed the responsibility of shooting 14 navy employees who were going from Gwadar to Karachi ${ }^{46}$ through bus. The then information minister of Balochistan Zahoor Buledi said that, "they identified non-Baloch by checking their identity cards and employee cards. ${ }^{47}$ Most of the Baloch groups have strong conviction that non Baloch ethnic identities have been accommodated in the province at the cost of locals. That is the reason that these groups are against the inclusion of people from other provinces specially from Punjab in CPEC project. Besides this, BRAS became a major concern when Foreign Minister of Pakistan, Shah Mehmood Quershi identified their safe hideouts in Iran. He stated that, "the training camps and logistical camps of this new alliance... are inside the Iranian border region. $" 48$

\section{Balochistan Student Organization (BSO) - Azad}

BSO was founded in 1967, which is now one of the largest ethnic based student body in Pakistan. It was proscribed as a terrorist group and was banned on March 15, 2013. ${ }^{49}$ It has been using the contemporary tactics of reaching out the audiences. Therefore, the group is very active in using electronic and social media. I have also observed that BSO-Azad is very active on Twitter and Facebook. On Twitter, BSO-Azad have $17.4 \mathrm{k}$ followers and they regularly update and respond through their account. Their post reflects a strong resentment towards the federation and law enforcement agencies.

46 The route is also named as Makran Coastal Highway.

47 Asad Hashim, “Gunmen Kill 14 Bus Passengers in Pakistan's Balochistan,” Al Jazeera, April 18, 2019,https://www.aljazeera.com/news/2019/04/gunmen-kill-buspassengers-pakistan-balochistan-official-190418045138814.html See also, Naimat Khan, "14 Bus Passengers Killed in Balochistan Terror Attack," Arab News, April 18,2019, https://www.arabnews.com/node/1484641/world.

48 Shahabuddin Shahab, "Pakistan asks Iran to Act on Militants behind Baluchistan Killings," Reuters, April 20, 2019, https://www.reuters.com/article/us-pakistaniran/pakistan-asks-iran-to-act-on-militants-behind-baluchistan-killingsidUSKCN1RW0EQ.

49 National Counter Terrorism Authority, "73 Organizations Proscribed by Ministry of Interior u/s 11-B-(1) r/w Schedule-I, ATA 1997," accessed December 10, 2019, https://nacta.gov.pk/wp-content/uploads/2017/08/Proscribed-OrganizationsEng.pdf. 
Maryam Azam

\section{Sectarian formations in Balochistan}

Generally, Baloch consider themselves as secular in terms of religious beliefs, but there are certain pockets where religious grounds are a source of cooperation and conflict. In this context, particularly, since 2001, sectarian militancy in Balochistan increased mainly due to the inclusion of sectarian militant groups, presence of Taliban, nexus of intra militant groups and external funding to destabilize the province. In addition to that, growing influence of Iran and its funded madaris have also been reported by the local population. On the other hand, the inclusion of people coming from Afghanistan after 2001, also contributed in accelerating sectarian divide. Hazara Shia community ${ }^{50}$ has been the main target of militants in the province who reside near Quetta. ${ }^{51}$ In this connection there are two main sectarian formations in Balochistan which reflect militant manifestations, i.e. sectarian based madaris and sectarian militant groups.

\section{Sect based Madaris}

Sectarian militancy is a major local security issue in Pakistan since 1980s. Formation of sect based organizations on sectarian lines created a web of sharp religious dissent within religious community. Sectarian divisions have gradually increased in Balochistan as well. It was revealed by the conversations with locals that sectarian fault lines are deep rooted and intense in certain parts of the province, particularly in Quetta, its adjacent areas and bordering areas of Balochistan with Afghanistan. The focus group were convinced with this fact that Sunni madaris are funded by

50 The total population of Hazara community is 900,000. See also, Maisam Iltaf, "Hazaras Gripped by Religious Extremism in Balochistan," Diplomat, April 16, 2019, https://thediplomat.com/2019/04/hazaras-gripped-by-religious-extremism-inbalochistan/; and Imran Yousaf, "Who are the Hazara?" Express Tribune, October 5, 2011, https://tribune.com.pk/story/267225/who-are-the-hazara/.

51 The two main localities of Hazara community in Quetta are in Hazara Town and Mari Abad. Also see Farhan Siddiqi, "Sectarian Violence in Balochistan," Middle East Institute, June 18, 2015, https://www.mei.edu/publications/sectarian-violencebalochistan . They also reside in other parts of Balochistan which includes Sanjawi, Much, Zhob, Harnai, Loralai, and Dukki. 
Saudi Arabia and other external sources and Shia madaris are supported by Iran. They not only provide education but also provide free boarding and lodging which is one of the main incentives for the poor locals to send their children in such institutes. According to one report, it was revealed that approximately 234 madrassas in Balochistan are getting external funding by the Muslim countries. In addition to that, 3000 madrassas out of 5441 are not registered under madrassa registration act. ${ }^{52}$ The gradual urbanization of certain parts of Balochistan has also contributed in bringing religious elements in the social landscape of the province. ${ }^{53}$

\section{Laskar e Jhangvi (LeJ)}

LeJ emerged as a militant splinter group of Sipha Sahaba Pakistan (SSP) in Punjab in 1990s, but later it expanded their activities across Pakistan in post 2001 years. The operational dynamics of the group extensively changed after $2001^{54}$ as it connected with other militant groups including Tehrik Taliban Pakistan (TTP), transnational groups like Al Qaeda along with small local militant pockets on sectarian lines in provincial centers including Lahore, Karachi, Quetta and Peshawar. One of the main factors is the bleak security environment of Balochistan after the assassination of Akbar Bughti in 2006, which fueled another series of insurgency in Balochistan and provided space for militants to operate. In addition to that, the spillover effect of war in Afghanistan also increased transnational militant networking between Taliban and LeJ along with other groups. They also had links within the tribal belt which connected them with the new militant nexus developed in Pakistan after 2001. LeJ is one of the most

52 Zahid Gishkori, "234 Madrassas in Balochistan Receive Foreign Cash: Official," Express Tribune, February 20, 2015, https://tribune.com.pk/story/841298/counteringextremism-in-balochistan-234-madrassas-receive-foreign-cash-official/.

53 For details see, Muhammad Amir Rana, "Religion, Nationalism and Insurgency in Balochistan," Dawn, July 14, 2019, https://www.dawn.com/news/1493929; and "Balochistan: An Easy target," Herald, July 1, 2019, https://herald.dawn.com /news/1398915.

54 In 1990s their operational base was confined to some parts of Punjab and Karachi. Besides this targeted sectarian killing, remote control explosions were their main modus operandi but after 2001 they became more intense in their operational tactics. They were involved in the acts of suicide bombing, national and transnational militant activities along with targeting of law enforcement agencies. 
lethal militant groups in Pakistan, which also targeted the Shia community across Pakistan. Half a million Hazara community, belonging to Shia theology of Islam has been the main target of LeJ in Balochistan, particularly since 2008. Geographically, there are two main target regions, one is Quetta and its surrounding areas and other is the land route including Mastung, Nushki, Dalbandin and Taftan border used by the Shia Muslims to visit their holy sites in Iran. A bus driver narrated an incident of 2011, when a bus carrying pilgrimage to Iran was attacked by LeJ. They asked who the Sunnis were, and asked for names. Then they told the Sunnis to run. We jumped and ran for our lives. But while they allowed everybody who was not a Shia to get away, they made sure that the Shias stayed on the bus. Then they made them get out and opened fire. ${ }^{55}$

The year of 2013 was one of the deadliest years for Hazara community as total of 180 people were killed and 310 were injured by LeJ attacks. From 2001-2017, 524 people from Hazara community were killed and 733 were injured. ${ }^{56}$ In April 2019, despite increased security measures, Hazaras were targeted in a suicide attack in a market located in Quetta. ${ }^{57}$ One of the respondents shared that LeJ has been very damaging for Quetta. In post 2001 years, LeJ was able to recruit the local Baloch mainly from Brahui tribe along with tribes giving it a local color.

\section{Presence of Shia pockets}

A fundamental difference between Sunni and Shia in terms of sectarian militancy is their organizational tendency. Sunni- Deoband work in formal structured groups whereas Shia grouping is more unstructured. As per the local response, Iranian influence in bordering areas of Balochistan has significantly increased. Shia madaris are heavily funded by external sources.

55 Human Rights Watch, "We are the Walking Dead: Killings of Shia Hazara in Balochistan, Pakistan,” June 29, 2014, https://www.hrw.org/report/2014/06/29/weare-walking-dead/killings-shia-hazara-balochistan-pakistan.

56 National Commission for Human Rights Pakistan, "Understanding the Agonies of Ethnic Hazaras," report, (Islamabad: National Commission for Human Rights, 2018), 18-24, https://nchr.gov.pk/wp-content/uploads/2019/01/HAZARA-REPORT.pdf.

57 Syed Ali Shah, "20 killed, 48 injured in Attack Targeting Hazara Community in Quetta," Dawn, April 12, 2019, https://www.dawn.com/news/1475621. 


\section{The Taliban and Al Qaeda}

Quetta and adjacent areas are closer to Afghanistan and the tribal belt falls in the north of these areas. This geographical location explicates the influx of Taliban from Afghanistan to Quetta after US attack on Afghanistan in October 2001, and later from the tribal belt. Quetta shura, which has been the main decision making body of Taliban under Mullah Omer has been reportedly operated from Quetta. ${ }^{58}$ Likewise, the tribal belt in parts of Balochistan, also became a melting pot for Taliban and foreign factions residing in Afghanistan. Consequently, it brought religion based militant formations in the province as well. In 2016, Taliban leader Mullah Akhtar Mansur was killed in Balochistan ${ }^{59}$ when his vehicle was targeted by a US drone strike. ${ }^{60}$

\section{Al Qaeda}

Al Qaeda, a transnational terrorist organization had its presence in certain parts of Pakistan, particularly when their base camp was dislodged from Afghanistan in post September 2001 scenario. Their diffusion towards the frontier areas created a bleak security situation in Pakistan. Al Qaeda's compartmentalization as an organization working in different regions with a distinct command and control systems has favored it as an organization to expand and operate in a larger space. Al Qaeda has also been reportedly operating in pockets in Balochistan. Their linkage with LeJ has also been identified by the law enforcement agencies, mainly due to their common

58 Declan Walsh, "Taliban's leadership Council Runs Afghan War from Pakistan," Guardian, January 29, 2010, https://www.theguardian.com/world/2010/jan/ 29/taliban-quetta-shura. See also, Mukhtar A. Khan, "Quetta: The Headquarters of the Afghan Taliban," CTC Sentinel 2, no. 5 (May 2009), https://ctc.usma.edu/wp-content/uploads/2010/06/Vol2Iss5-Art2.pdf.

59 It was reported that Mullah Mansur was traveling from Taftan, a border town in Chaghi district in Balochistan province which is about about 600 kilometers from Quetta.

60 Ali Akbar, "Afghan Taliban Chief Mullah Mansour Killed in Balochistan," Dawn, May 22, 2016, https://www.dawn.com/news/1259979. 
Maryam Azam

anti-Shia stance. In this context. Operation Radd ul Fassad has been a successful counter terrorist operation to dismantle its presence.

\section{Tehrik Taliban Pakistan (TTP)}

TTP has been one of the most lethal militant groups in Pakistan which has challenged the writ of the government across country by invariably targeting government, law enforcement agencies and civilians. Though, TTP had its stronghold in the tribal belt but it has expanded its activities and facilitators in different parts of Pakistan. Due to political instability, fragile security environment and rising religious extremism, Balochistan was a suitable terrain for TTP. Reportedly, TTP has managed to keep its presence near the Pashtun areas and areas bordering Afghanistan. ${ }^{61}$ Several media briefings by armed forces have revealed the existence of TTP in Balochistan. For instance, a TTP facilitator with weapons and improvised explosive devices (IED) were recovered from Zhob, Balochistan. ${ }^{62}$ In January 2019, TTP conducted a gun and suicide attack in DIG police office in Lolarai killing nine people. Along with this, TTP claimed the responsibility of killing six levies in Ziarat. ${ }^{63}$ Hence, pockets of TTP operating in Balochistan explain the foot prints of religion based militant activities in the province.

\section{Hizbul Ahrar}

61 For instance, reportedly, Zhob, Loralai, Chaman, Qilla Saifullah and Panjpai are hideouts of TTP. For details see, Amjad Bashir Siddiqi, "TTP Expands Footprint in Balochistan as Quetta Safe City Project Remains in Limbo," News, April 10, 2019, https://www.thenews.com.pk/print/455689-ttp-expands-footprint-in-balochistan-asquetta-safe-city-project-remains-in-limbo.

62 "TTP Facilitator Apprehended, Large Caches of Weapon Seized in Balochistan: ISPR," Dawn, November 3, 2017, https://www.dawn.com/news/1368146.

63 Muhammad Zafar, "Nine Martyred in Gun-and-Suicide Attack on DIG Office in Loralai," Express Tribune, January 29, 2019, https://tribune.com.pk/story/1899305/1least-five-injured-loralai-terroristattack/?_cf_chl_jschl_tk_=466e760674dae914a1e108c807dd1cded9b4bb961578241473-0-AX5zQm6pDw1OgyzabB7c6ZMIulwWxTkU27NkDSBC4fpikV_0wv2gWvXGd82H44RsCMc4sdAMZ OvfHNyAVQcnpCOHL-4KJmWt. 
Hizbul Ahrar, a splinter group of Jammat ul Ahrar (JuA) has been seen active in Balochistan in the recent years. It has allegiance with TTP as well. It was proscribed and banned as a militant group in 2019, by the government of Pakistan. It is said to be led by Mukarram Khan ${ }^{64}$ in Nangarhar, Afghanistan, after breaking away from TTP and JuA. ${ }^{65}$ Their main target has been the security forces including police and army having their anti-state posture. ${ }^{66}$ In April 2018, they started their offensive against the security forces by attacking police in Quetta city which resulted in six casualties. ${ }^{67}$

\section{Difa e Balochistan /Balochistan Musalla Defah Tanzeem (BMDT)}

The formation of Difa e Balochistan underlines another trend in Baloch militancy as it is a religiously and ethnically motivated group led by a Baloch, Shafiq Mengal. ${ }^{68} \mathrm{He}$ is reportedly inspired by Jammat ud Dawa and has been a part of their activities. Later, he formed his own group which has been mostly active in Khuzdar District. It was proscribed by the government of Pakistan on September 8, 2010. ${ }^{69}$ It also worked under the name of Haq na Tawar ${ }^{70}$ when it developed its base and safe hide out in Tootak town in Khuzdar district in 2011. In 2014, mass graves were discovered in Khuzdar by the local people. It was reported that Shaiq

64 He belongs to Mohmand agency, Pakistan.

65 "Taliban Splinter Group Splits Further over Tactics," Nation, November 12, 2017, https://nation.com.pk/12-Nov-2017/taliban-splinter-group-splits-further-over-tactics.

66 See, Annexure II.

67 Animesh Roul, “Hizb ul-Ahrar: Pakistan's Cross-border Taliban Problem Remains Critical," Terrorism Monitor XVII, no. 23 (December 2019): 7-9.

68 Shafiq-Ur-Rehman, Mengal clan, who live in Wadh and Khuzdar. He is the son of Naseer Mengal, ex-Chief Minister Balochistan and later became Pakistani Federal Minister of petroleum and natural resources. He studied in Aitchison College but was dropped from the school. Later he joined a Deobandi Seminary in Karachi from where he created links with the religious outfits. For details see, "State's Deadly Weapon, Shafiq Mengal - The Balochistan Post Report," Balochistan Post, September 19, 2017, https://thebalochistanpost.net/2017/09/states-deadly-weaponshafiq-mengal-balochistan-post-report/.

69 National Counter Terrorism Authority, "78 Organizations Proscribed by Ministry of Interior u/s 11-B-(1) r/w Schedule-I, ATA 1997.”

70 It means righteous in Brahvi language. 
Mengal's group might be behind these killings. Working of the group and leadership of Shafiq Mengal has been critical and controversial. It is perceived that on one hand it has links with the other banned religious based militant group. On the other hand, it is perceived that this group has been involved in countering the other Baloch nationalist militant groups. For this reason, their alleged link with security agencies to operate against the other banned militant groups has been reported, ${ }^{71}$ which makes it critical among other militant groups as well as to the security forces. In 2018, Shafiq Mengal was allowed to contest general elections as an independent candidate from NA-269 where he had local support of tribal leaders. ${ }^{72}$ This kind of penetration further complicates the case of militancy in the province keeping in view the fact that they had strong local backdrop.

\section{Islamic State (IS)/Daesh}

Islamic state expanded its operational activities from Middle East to South Asia in 2015, by announcing Islamic State of Khorasan for the region including Afghanistan, Pakistan and India. Later, in post Baghdadi period in 2019, IS further compartmentalized the organizational structure and announced the formation of Waliyah Pakistan which reportedly exists in small pockets in Balochistan and tribal areas in particular. In this context, Balochistan and the tribal belt became a melting pot for militant activities and hideouts. IS presence in these remote areas questions the security apparatus of the state as well. It is evident that those areas which are poorly governed and are more volatile, become malleable places for militants, as

71 For Details, see, , "State's Deadly Weapon, Shafiq Mengal - The Balochistan Post Report," Balochistan Post; and Asian Human Rights Commission, "More than 100 Dead Bodies from Three Mass Graves were found in One District Of Balochistan," press release, January 27, 2014, https://reliefweb.int/report/pakistan/more-100-deadbodies-three-mass-graves-were-found-one-district-balochistan; and Database of People with Extremist Linkages, "Baloch Musalla Dafa Tanzeem," last accessed December 16, 2020, https://www.dopel.org/BMDT.htm.

72 James M. Dorsey, "Pakistan and Its Militants: Who is Mainstreaming Whom?”(paper, S. Rajaratnam School of International Studies, 2018), https://www.jstor.org/stable/pdf/resrep19932.pdf?refreqid=excelsior\%3Af25dc476e 9 4faa25c5f20908d4751744. See also, Naimat Khan, "Elections in Balochistan's Khuzdar Unite Foes, Ideological Opponents," Arab News, July 24, 2018, https://www.arabnews.pk/node/1342261/pakistan. 
happened in Pakistan in the tribal region and Balochistan as well. IS militants and its affiliates have targeted law enforcement agencies as well as civilians in Balochistan. ${ }^{73}$ There are different opinions regarding the nature and existence of IS in Pakistan. In addition to it, due to different ideology, lack of local support and connections and ongoing counter operations by armed forces of Pakistan have contributed in restraining IS activities in the region. ${ }^{74}$

\section{Sectarian groups that function between Pakistan and Iran}

Jandullah, a Sunni militant group has been functional in the Iranian province of Balochistan along with parts of Balochistan and Karachi in Pakistan. They have been reportedly involved in cross border activities. ${ }^{75}$ In addition to that, Karachi chapter of the group in particular has been very active in high profile attacks. Due to their similar ideological foundations, they have allegiance towards Al Qaeda and TTP as well. According to reports, Jaish al Adl (Army of Justice) emerged as its successor in 2012, led by Salahuddin Farooqui which operates across 950 kilometers of Pakistan-Iran border. They claimed the responsibility of killing 27 Iranian revolutionary guards in February 2019. Consequently, Iranian government claimed its operation from Pakistani soil. ${ }^{76}$ It is reported that they were getting support from Baloch groups as well. ${ }^{77}$

73 See, Annexure III.

74 Abdul Basit, "IS Penetration in Afghanistan-Pakistan Assessment, Impact and Implications," Perspectives on Terrorism 11, no. 3 (June, 2017): 19-20, https://www.jstor.org/stable/26297839. Also See, Farhan Zahid, "IS Footprint in Pakistan: Nature of Presence, Method of Recruitment, and Future Outlook," Counter Terrorist Trends and Analyses 9, No. 5 (May 2017): 9-12 (11), https://www.jstor.org/stable/pdf/26351518.pdf.

75 Zahid, "IS Footprint in Pakistan," 159.

76 Shahabuddin Shahab, "Pakistan Asks Iran to Act on Militants behind Baluchistan Killings," Reuters, April 20, 2019, https://www.reuters.com/article/us-pakistan-iran-idUSKCN1RW0EQ.

77 AFP, "Jaish al-Adl: Shadowy Sunni Extremists on Iran-Pakistan Border," France 24, February 2, 2019, https://www.france24.com/en/20190214-jaish-al-adl-shadowysunni-extremists-iran-pakistan-border. 


\section{Linkages Between Militant Groups}

\begin{tabular}{|c|c|c|c|}
\hline $\begin{array}{l}\text { Linkages within } \\
\text { Baloch } \\
\text { Nationalistic } \\
\text { Groups }\end{array}$ & $\begin{array}{l}\text { Linkages within } \\
\text { Baloch and } \\
\text { Sectarian } \\
\text { Militant } \\
\text { Groups }\end{array}$ & $\begin{array}{l}\text { Linkages within } \\
\text { Baloch } \\
\text { Transnational } \\
\text { and International } \\
\text { militant Groups }\end{array}$ & $\begin{array}{l}\text { Linkages } \\
\text { within } \\
\text { Religious based } \\
\text { militant groups }\end{array}$ \\
\hline $\begin{array}{l}\text { BRAS-an } \\
\text { alliance between } \\
\text { Baloch } \\
\text { Liberation Army } \\
\text { (BLA), Baloch } \\
\text { Liberation Front } \\
\text { (BLF) and } \\
\text { Baloch } \\
\text { Republican Army } \\
\text { (BRA) }\end{array}$ & $\begin{array}{l}\text { Connections of } \\
\text { Laskar e Jhangvi } \\
\text { (LeJ) with BLA, } \\
\text { BRA and UBA }\end{array}$ & $\begin{array}{l}\text { Linkages reported } \\
\text { between BLA and } \\
\text { IS }\end{array}$ & $\begin{array}{l}\text { Lashkar e } \\
\text { Jangvi (LeJ) } \\
\text { connections } \\
\text { with Tehrik } \\
\text { Taliban Pakistan } \\
\text { (TTP) }\end{array}$ \\
\hline $\begin{array}{l}\text { Connectivity } \\
\text { between BLA } \\
\text { and BLF }\end{array}$ & & $\begin{array}{l}\text { Connections } \\
\text { between BRA and } \\
\text { Jandullah }\end{array}$ & $\begin{array}{l}\text { LeJ/ LeJ Al } \\
\text { Almi linkages } \\
\text { with IS/ Al } \\
\text { Qaeda }\end{array}$ \\
\hline
\end{tabular}

\section{Global power muddling in Balochistan}

Balochistan has become a part of regional and global corridor politics because of CPEC and Gwadar port project. Chinese planned investment of 62 billion dollars ${ }^{78}$ illustrates the strategic value of this area which has been subject to deep internal divisions. US approach towards this area has also been critical. In 2012, the way US Senate committee on foreign relations

78 Madiha Afzal, "At All Costs: How Pakistan and China Control the Narrative on the China-Pakistan Economic Corridor," Brooking Institution, June 2020, 1-10, https://www.brookings.edu/research/at-all-costs-how-pakistan-and-china-control-thenarrative-on-the-china-pakistan-economic-corridor/. 
discussed the Balochistan issue, it was condemned by Pakistan at national level. Moreover, support for an independent Balochistan by few US senators provides an insight into the thinking pattern that prevails in the US policy circles. ${ }^{79}$ Moreover, socio political and strategic realities of Afghanistan and Iran has a profound influence on overall security environment of the province. Besides this, federal government, spokesperson of armed forces and intelligence reports on India's role in destabilizing the area is yet another factor which supports militant manifestations in Balochistan. Arrest of Kulbhoshan Yadev, an Indian serving naval officer on account of spying in 2016 in Balochistan, has further reinforced the claim of Pakistan. After the arrest of Yadev, the security officials revealed that he had links with the separatist elements in Balochistan. During interrogation, his own statements endorsed Indian alleged involvement in Balochistan. It is pertinent to note that the Indian support to the militant groups has been repeatedly endorsed by the government and security forces of Pakistan. It is notable that number of news websites and Twitter accounts operated from India extensively posted material related to Balochistan, mostly in support of the Baloch separatist groups including BLA, BLF, BRA and BRAS.

\section{Conclusion}

These existing explorations related to the issue of Balochistan reflects the deep rooted local polarization, deprivation, desperation and an overall disposition of socio-political structure of the state which provides militants an easy hideout and place to operate. Moreover, political instability, systemic flaws, societal grievances and formation of ethnic and religious

79 US Congressman Dana Rohrabacher introduced a resolution in the US House of Representatives, which was co-sponsored by House Representative Louie Gohmert and Steve King. The motion called upon Pakistan to recognize the Baloch right to self-determination. It was condemned by then government of Pakistan and opposition parties as well. See, Huma Imtiaz, "US Congressman Tables Bill for Baloch Right to Independence," Express Tribune, February 18, 2012, https://tribune.com.pk/story/ 338079/us-congressman-tables-resolution-calling-for-independence-of-baloch/. 
Maryam Azam

clusters illustrate the context of militancy in Balochistan. The institutionalization of ethno separatist and sectarian formations have strengthened militant nexus in the province. In the recent years, the nexus within the nationalistic separatist militant groups and between religion based militant groups and nationalistic separatist groups entails a new trend in Baloch militancy which would not only strengthen the militant manifestations but would also make the conflict in Balochistan more complexed. Another significant aspect is the geographical location of Balochistan which provides a safe haven for militants to operate and connect across the border as well. That is the reason that after military operation in the tribal belt of Pakistan, mostly religiously grounded and transnational militant groups shifted their activities in Balochistan. They are now being contained by the armed forces of Pakistan through different intelligence based operations and fencing of border. Another important factor in the destabilization is the connection of nationalistic separatist groups and their support from external actors, particularly India, which too makes the case of militancy in Balochistan more complicated. Despite this, it is significant to understand that use of force is one major element to contain militancy but a greater effort is required to eradicate and contain the roots and shoots of militancy at the socio political and economic end. Explicitly, to address and weaken the call of separation, the government needs to focus on social and infrastructural development to reduce grievances and deprivation of the local population. It is pertinent to note that militant tendencies in Balochistan are comparatively low in those areas where literacy rate is high. Local responses were convinced with this reality that education can act as a revolutionary force in providing awareness, empowerment and a positive vision to the youth of the province. One of the respondents shared that, "education sector has been uplifted when Dr. Abdul Malik was the Chief Minister. Now my university bus picks me from my village which has a distance of one hour and after university hours drops me as well. For people living in other provinces like Punjab, it would be a routine matter, but it is like a revolution for me in Balochistan." 80 Similarly, communication and transportation creates connectivity,

${ }^{80}$ The interviewee belongs to University of Turbat, Balochistan. 
opportunities and mobility within the society. Balochistan has been far behind in infrastructural development. One of the respondents shared his observation and told that, 'I went to an area of Pashtun Belt and saw that houses were built with stones... there was no road, electricity, basic sanitation and water facility in the area. They were really living in the stone age even in the $21^{\text {st }}$ century... how come then we expect them to be with the state.' Another interviewee from Makran belt shared that, 'we have no health facilities, we have to go to Karachi even for basic medical facility and treatment. Everyone cannot afford to travel to Karachi. ${ }^{\prime} 81$ Therefore, political will, trust between the people and the federation, an acceptable consensus oriented security apparatus and pragmatism is required to eradicate militant manifestations in Balochistan.

Education

Annexure I

District wise literacy Rate in Balochistan

\begin{tabular}{|l|l|}
\hline \multicolumn{1}{|c|}{ District } & Literacy level (10+) in percentage \% \\
\hline Ziarat & 34.3 \\
\hline Zhob & 16.8 \\
\hline Sibi & 25.47 \\
\hline Quetta & 57.1 \\
\hline Pishin & 31.1 \\
\hline Panjgur & 31.4 \\
\hline Nasirabad & 12.7 \\
\hline Musakhel & 10.4 \\
\hline Mastung & 27.6 \\
\hline Loralai & 20.5 \\
\hline Lasbela & 22.3 \\
\hline Kohlui & 12.1 \\
\hline Killa Saifullah & 17.6 \\
\hline Killa Abdullah & 16.1 \\
\hline Khuzdar & 17.4 \\
\hline Kharan & 15.1 \\
\hline Kech & 27.5 \\
\hline Kalat & 19.9 \\
\hline Jhal Magsi & 12.3 \\
\hline
\end{tabular}

${ }^{81}$ It took around 8 hours 43 minutes to travel from Makran belt to Karachi by road. 
Maryam Azam

\begin{tabular}{|l|l|}
\hline Jaffarabad & 18.5 \\
\hline Gwadar & 25.5 \\
\hline Dera Bugti & 11.7 \\
\hline Chagai & 27.0 \\
\hline Bolan & 15.7 \\
\hline Barkhan & 15.7 \\
\hline Awaran & 14.8 \\
\hline
\end{tabular}

Source: Pakistan Bureau of Statistics

\section{Annexure II}

Hizbul Ahrar activities in Balochistan, Pakistan

\begin{tabular}{|c|l|}
\hline \multicolumn{1}{|c|}{ Date } & \multicolumn{1}{|c|}{ Incident } \\
\hline $\mathbf{2 4}^{\text {th }}$ April 2018 & $\begin{array}{l}\text { Suicide bombing in Quetta, six policemen } \\
\text { killed and 16 injured }\end{array}$ \\
\hline $\mathbf{1 7}^{\text {th }}$ May 2018 & $\begin{array}{l}\text { Attack on Frontier Corps' Madadgar } \\
\text { Centre in Quetta }\end{array}$ \\
\hline $\mathbf{2}^{\text {nd }}$ June 2019 & $\begin{array}{l}\text { Attack on paramilitary forces , Hub } \\
\text { Lasbela }\end{array}$ \\
\hline $\mathbf{7}^{\text {th }}$ January $\mathbf{2 0 2 0}$ & $\begin{array}{l}\text { Motorcycle bomb blast attack on the } \\
\text { Frontier crop vehicle, near a hospital in } \\
\text { the Mecongi road shopping area in Quetta }\end{array}$ \\
\hline
\end{tabular}

Source: Hafeezullah Sherani, "FC Personnel kill 5 Suspected Suicide Bombers who Attacked Madadgar Centre in Quetta," Dawn, May 17, 2018, https://www.dawn.com/ news/1408276; and Pakistan Security Report 2018-2019, report (Islamabad: Pakistan Institute of Peace Studies, 2019).

\section{Annexure III}

\section{IS activities in Balochistan, Pakistan}

\begin{tabular}{|c|c|}
\hline \multicolumn{1}{|c|}{ Date } & $\begin{array}{c}\text { Incident } \\
\mathbf{2}^{\text {nd }} \text { April 2018 }\end{array}$ \\
\hline $\mathbf{2 5}^{\text {th }}$ July 2018 & $\begin{array}{c}\text { Four Christians were killed in Quetta } \\
\text { A suicide blast took place in Quetta } \\
\text { killing 31 people and 70 were injured }\end{array}$ \\
\hline $\mathbf{1 2}^{\text {th }}$ April 2019 & $\begin{array}{c}\text { Suicide attack in Quetta killing 20 people } \\
\text { and 48 injured }\end{array}$ \\
\hline $\mathbf{1 0}^{\text {th }}$ January 2020 & $\begin{array}{c}\text { Attack on mosque in Quetta in which 14 } \\
\text { people were killed and 20 were injured }\end{array}$ \\
\hline
\end{tabular}

Source: AFP, "Islamic State Claims Deadly Pakistan Fruit Market Bombing" France 29, April 13, 2019, https://www.france24.com/en/20190413-islamic-state-claims-deadlypakistan-fruit-market-bombing; Pakistan Security Report 2018-2019, report (Islamabad: Pakistan Institute of Peace Studies, 2019); and Asad Hashim and Saadullah Akhter, 


\section{Mapping Militant Manifestations in Balochistan}

"Bomb Attack Targets Worshippers at Quetta Mosque, Killing 14," Al Jazeera, January 10, 2020, https://www.aljazeera.com/news/2020/1/10/bomb-attack-targets-worshippers-atquetta-mosque-killing-14. 